\title{
Revisiting the Effect of Crude Oil Price Movements on US Stock Market Returns and Volatility
}

\author{
Ralph Sonenshine, Michael Cauvel \\ Economics Department, American University, Washington DC, USA \\ Email: Sonenshi@american.edu,mc1465a@student.american.edu
}

How to cite this paper: Sonenshine, R. and Cauvel, M. (2017) Revisiting the Effect of Crude Oil Price Movements on US Stock Market Returns and Volatility. Modern Economy, 8, 753-769.

https://doi.org/10.4236/me.2017.85053

Received: February 2, 2017

Accepted: May 20, 2017

Published: May 23, 2017

Copyright ( 2017 by authors and Scientific Research Publishing Inc. This work is licensed under the Creative Commons Attribution International License (CC BY 4.0).

http://creativecommons.org/licenses/by/4.0/

\section{(c) (i) Open Access}

\begin{abstract}
From mid-2014 to 2016, oil prices plunged rapidly causing significant volatility in the US and global equity markets. This change in crude oil prices occurred after a significant run up in oil prices three to four years earlier. Each change in the growth trajectory of oil prices affects stock market returns. How and why do oil price shocks affect the expected stock market returns among key sectors of the economy? This paper explores this issue by examining how the magnitude of crude oil price changes affects the stock market returns and variances of key producing, banking and consuming segments of the US economy. Our findings provide some explanations for the asymmetric responses to positive and negative oil shocks found in these key sectors of the economy.
\end{abstract}

\section{Keywords}

Abnormal Returns, Event Study, Oil Shocks

\section{Introduction}

Starting in mid-2014 crude oil prices began to plunge causing dislocation in many parts of the US and world economy. Key parts of the oil and gas complex were drastically impacted by the plunge in oil prices; in addition, other parts of the economy, particularly the banking and oil consuming sectors, were also affected.

Explanations for changes in crude oil prices vary, depending on the duration, direction, timing, and depth of the shock. Demand shocks can be caused by macroeconomic concerns, particularly recessions, or changing usage among key oil consuming countries. Other more structural demand issues, such as the changing profile of crude oil usage in transportation and industrial applications, could 
also impact crude oil demand. Often, however, it is unclear whether severe oil price fluctuations are due to short or medium-term cyclical changes, or longer-term structural adjustments. The same can be said for positive increases in crude oil demand or positive oil shocks.

Crude oil price shocks can also be attributed to supply issues, whether it is oversupply due to new oil exploration (e.g. US shale production), technological developments that improve drilling efficiency, or government activities (e.g. Iranian oil entering the world market after a prolonged embargo period). Supply disruptions caused by weather, terrorist attacks, or other government dealings can also affect the market.

Given the constant variation in crude oil prices and the apparent influence that crude oil prices have on the health of many businesses and economic sectors, investors may be uncertain how to respond to crude oil price changes. Investor responses can suggest expectations regarding the direction and pace of economic activity as well as changing inflation expectations, and potential sectoral shifts in the economy. Investor responses can be viewed as an interpretation of the signals that oil price swings are providing regarding economic activity. This paper seeks to understand these signals by assessing how investors respond to major changes (plus or minus 20 percent) in oil prices. It is our contention that investor reactions to crude oil prices occur primarily during significant price swings. While the literature is replete with studies that assess the macroeconomic effect as well as the stock market effect of crude oil price changes, this study is the first to assess investor reaction to long-term, significant crude oil price shocks. To do so, we identify major trend changes in oil prices over a 10 year time period (2006 through 2015) and assess how investors react to these changes during a particular event window. We find that differential investor responses to oil shocks in the producing, consuming, and banking sectors. These responses vary by the depth, variation and velocity of the shock. We also find asymmetric responses in these sectors depending on whether the oil shocks are positive or negative.

The layout of the paper is as follows. Section 2 reviews the relevant literature. Section 3 discusses our data and empirical strategy. Section 4 presents our regression results, and Section 5 provides some concluding remarks.

\section{Literature Review}

While the effects of oil and gas price shocks have long been of interest to economists, most early work on the topic focused on the impact oil price shocks on business cycles and the macro economy ${ }^{1}$. Work in this area was strongly influenced by the notion that crude oil prices were a leading indicator of larger troubles-as Hamilton [1] pointed out, seven out of the previous eight recessions (at the time of publication) had been preceded by a dramatic increase in crude oil prices.

More recently, economists have begun to explore the relationship between oil 
prices and stock market returns. Since stock prices reflect investors' views of future earnings, analyzing the relationship between oil prices and stock market returns may yield valuable insights into the effect that oil price shocks have on expectations. Scholars, such as Ross [2], suggest that oil price volatility may be an accurate measure of the rate of information flow in financial markets, and therefore, may affect stock market returns. Thus, as expectations and stock market prices change with oil prices, overall economic activity may be affected as well. Ferderer [3], Lee et al. [4], and Sadorsky [5] all investigate this relationship and find that positive oil price shocks and greater volatility explain forecast errors in both industrial production and real stock market returns. They also reason that increased oil price volatility can weigh on investment returns as it increases the option value of waiting to invest.

On the surface, the relationship between oil prices and stock market returns seems straightforward: an increase in crude oil prices should theoretically benefit oil producers and hurt oil consumers. Existing research provides some evidence that this relationship generally holds. Huang et al. [6] find that oil futures returns have a positive impact on individual oil company stock returns, but an insignificant impact on broad-based market indices like the S\&P 500, suggesting the presence of offsetting negative effects on the oil consuming sector. Similarly, Hammoudeh and Li [7] found a positive association between oil prices and equity returns for oil producers but a negative association with the broad-based MSCI World Index. Several other studies have found the expected positive relationship between oil prices and the stock market returns of oil and gas companies [8] [9]. There is further evidence of variation in returns across industry subsectors [8], although some early studies found no significant effects [10] [11]. Similarly, there is some evidence that the stock market returns in the oil consuming sector respond negatively to oil price increases, at least in the case of the U.S. transportation industry [7].

While there is evidence that the basic relationship predicted by theory generally holds, additional research suggests a more nuanced connection may exist. Numerous studies provide evidence that the relationship between oil prices, economic activity, and stock market returns is asymmetric and nonlinear. Hamilton [12] argues that while rising oil prices retard economic activity and declining oil prices enhance it, there are costs to adjusting to oil prices in either direction. As a result, rising oil prices create two negative forces, while falling oil prices create one negative and one positive effect. Others, such as Balke et al. [13], suggest that the asymmetry can be explained by the relationship between rising oil prices and monetary policy, whereby higher oil prices suggest interest rate increases, thereby depressing economic and stock market activity. This result differs from Ferderer [3] who argues that the monetary policy response to oil shocks is similar between positive and negative shocks. He instead suggests that the asymmetry is caused by sectoral shocks and uncertainty, with greater volatility surrounding oil price rises than declines.

Conversely, Mohanty et al. [14] find that declining oil prices have a greater 
impact on stock market returns and volatility than rising oil prices. They argue that the asymmetric responses of the economy to energy price shocks may be attributed to three major factors: 1) the uncertainty effect on real consumption growth [15], 2) irreversible investment decisions made by business firms [16] [17], and 3) resulting sectorial shifts within an economy [3] [18] [19].

Mohanty et al. [14] further argues that asymmetric responses of the economy to energy price shocks are likely to result in decreased consumption in the economy, the postponement of investments, and reallocation of resources between declining and expanding industry sectors. The uncertain economic environment that follows will lead to concerns over future cash flows, putting pressure on stock market returns as well as increasing stock market volatility. In addition, the cost of capital for investment projects is likely to change, with large swings in oil prices causing investment to wane.

While agreeing with these effects of oil price changes, some economists, such as Huang et al. [6] and Hamilton [12], contend that oil price movements must reach a certain threshold to have a significant effect on stock prices. In other words, only large changes in the price of oil, either positive or negative, have a significant impact. Killian and Park [20] further argue that the cause of the oil price shocks is important in determining the effect. They find that the negative response of stock prices to oil price shocks occurs only when the price of oil rises due to an oil-market specific demand shock, perhaps driven by precautionary demand in anticipation of future crude oil supply shortfalls. In contrast, higher oil prices driven by an unanticipated surge in global output, may have a positive effect on stock market returns.

Thus, the existing literature suggests that the relationship between oil prices and stock market returns is more complex than it initially appears. This complexity may arise because changes in oil prices affect not only investors' evaluations of individual firms, but also their views regarding economy activity in general. Furthermore, the amount of attention that investors pay to oil price movements may vary at different times. While it seems that oil price movements may always contain valuable information relating to the future health of the economy, investors and speculators receive information from a multitude of sources on a continuous basis relating to a variety of issues. Therefore, it seems reasonable that only prolonged, significant oil price movements-and not short-term fluctuations-will have a key impact on investor sentiment and expectations. Therefore, examining periods of steep and continual increases or declines in oil prices may yield different results than those obtained by examining a longer time period and treating all shocks as equally important, which is the method undertaken in most of the studies in the literature. For example, while Mohanty et al. [14] use the event study methodology to highlight shocks that may be of great importance, they focus on short spikes rather than longer-term trends, and their threshold is relatively low -5 percent daily movement.

This paper aims to add to the literature by examining the relationship between crude oil prices and stock market returns, during prolonged periods of steep 
change in oil prices, both positive and negative. To the authors' knowledge, no study has yet been conducted to examine how this relationship differs during such periods.

Other studies have focused either on the effect of oil price changes on the overall stock market [20] or on individual firm returns [6] [14]. However, studies rarely assessed the impact at the sector or sub-sector level, though Mohanty and Nandha [8] and Hommoudeh and Li [7], are exceptions. Moreover, those who look at individual firms or sectors focus almost exclusively on the oil-producing sector ${ }^{2}$. Thus, through the use of electronic traded funds (ETFs) this study seeks to close this research gap by studying the impact of oil prices on the returns of key sectors and sub-sectors, including both oil producers, banking, oil consumers, and oil-neutral industries.

\section{Hypothesis, Data and Empirical Methodology}

\subsection{Hypothesis}

This paper analyzes the effect of crude oil price shocks on abnormal returns in the oil producing and consuming sectors as well as the banking sector over a 10 year time period from 2006 through 2015. We expect to find that oil shocks have varied effects by sector, with differences based on depth, variability, and velocity of the shock. We also expect these varied responses to differ for negative and positive shocks.

\subsection{Data}

Crude oil spot prices, as shown in Figure 1, were gathered from the US Energy Information Agency (EIA) from 2006 to 2015.

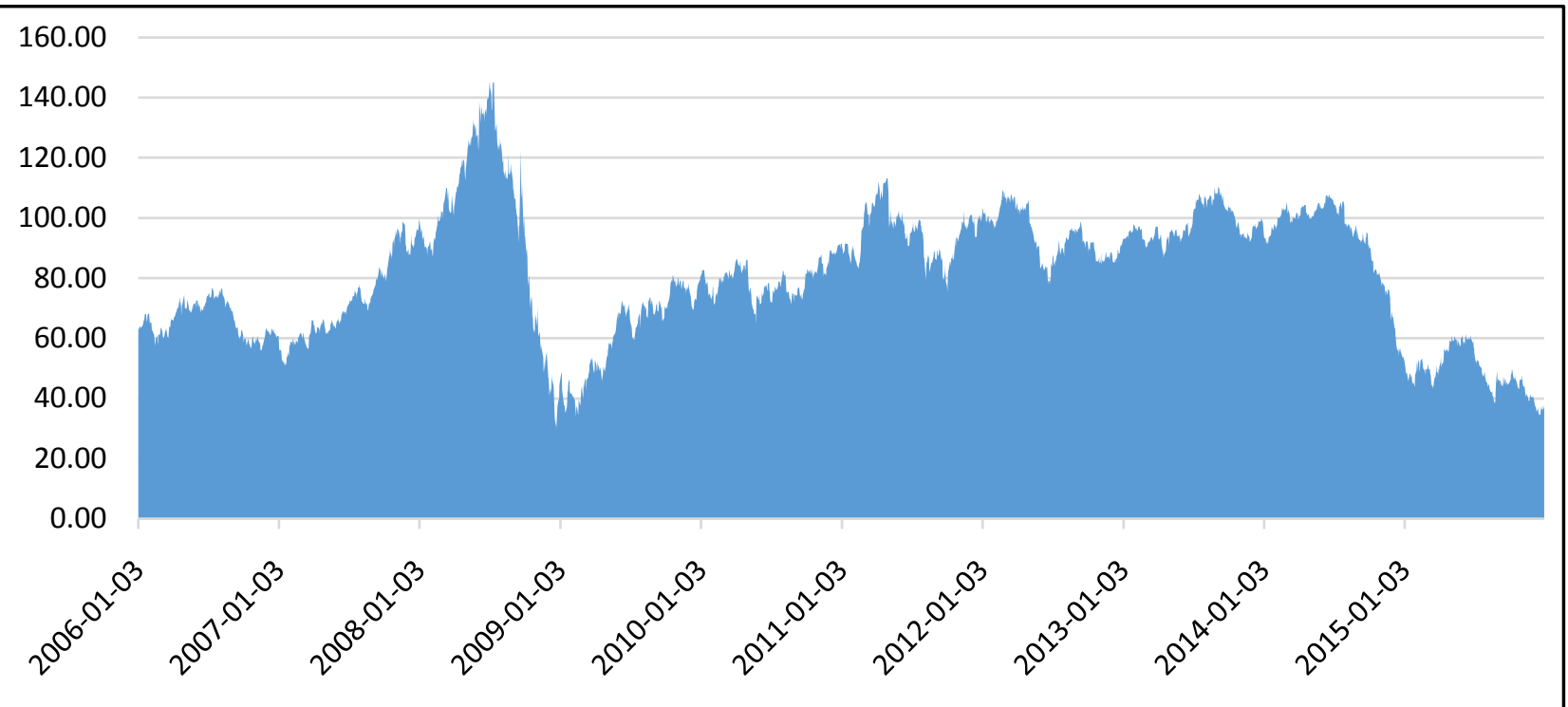

Figure 1. WTI crude oil spot prices-2006 through 2015.

${ }^{2}$ Hommoudeh and Li's (2005) study is a notable exception as they assessed the effects of oil price movements on the transportation industry, an oil consuming sector. 
In this time period, we examined WTI spot oil prices to assess periods of positive or negative shocks. To determine a shock or event, we calculated the daily WTI crude oil spot returns and looked at 60 day periods in which the percent change in the WTI spot oil price returns were greater than 20 percent in absolute value (the bear market threshold) for a period of 10 successive days or more. The procedure for determining an oil price shock is somewhat similar to Mohanty et al. [14], who identified shocks as a daily change in oil prices of plus or minus 5 percent. However, we are assessing longer-term changes in the direction of oil prices.

Using the above methodology we identified 10 shocks (6 positive and 4 negative). We then sought to identify how investors respond to these shocks. To do so, we used the event study methodology, defining event windows to compare responses to each of the 10 shocks. We defined an event window as the period starting at -10 days ( 0 being the end of the 60 day period) and ending $+5,+10$, or +30 , as shown in the following time line. We started the event window at -10 to incorporate the initial 10 consecutive days of greater or less than 20 percent change in oil price change from 60 days prior.

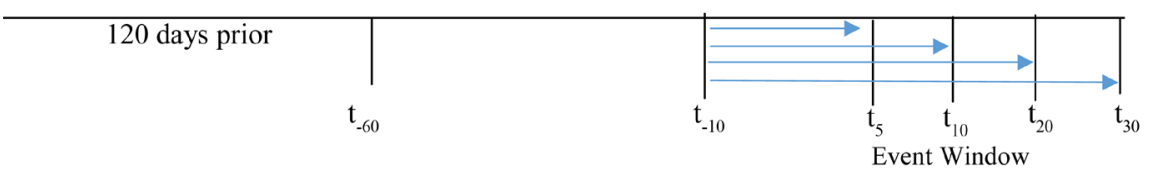

The 10 shocks we identified using the method of a rolling 60 day return of plus or minus 20 percent are shown in Table 1.

Although the sample stretches from 2006 to 2015, 7 of the 10 events occurred in two, 12 month time periods, the first being between mid-2008 to 2009 and the second between late 2014 and 2015. The two recession years of 2008 and 2009

Table 1. Oil and gas shocks.

\begin{tabular}{ccccccc}
\hline Events & Event Start Date & $\begin{array}{c}\text { Event End Date } \\
(-10,10)\end{array}$ & $\begin{array}{c}\text { Shock } \\
\text { Direction }\end{array}$ & $\begin{array}{c}\text { Average } \\
\text { Return } \\
(-60,0)\end{array}$ & $\begin{array}{c}\text { Standard } \\
\text { Deviation } \\
(-60,0)\end{array}$ & $\begin{array}{c}\text { Total } \\
\text { Shock }\end{array}$ \\
\hline 1 & $7 / 31 / 2015$ & $8 / 27 / 2015$ & Negative & $-38.5 \%$ & $6.21 \%$ & 18 \\
2 & $11 / 17 / 2014$ & $12 / 12 / 2014$ & Negative & $-23.3 \%$ & $6.84 \%$ & 76 \\
3 & $6 / 8 / 2012$ & $7 / 6 / / 2012$ & Negative & $-27.3 \%$ & $7.48 \%$ & 14 \\
4 & $9 / 4 / 2008$ & $10 / 2 / 2008$ & Negative & $-42.4 \% \%$ & $13.97 \%$ & 122 \\
Mean & & & & $-32.88 \%$ & $8.63 \%$ & 57 \\
5 & $5 / 29 / 2015$ & $6 / 26 / 2015$ & Positive & $23.2 \%$ & $4.34 \%$ & 19 \\
6 & $4 / 14 / 2011$ & $5 / 12 / 2011$ & Positive & $20.4 \%$ & $9.01 \%$ & 14 \\
7 & $4 / 29 / 2009$ & $7 / 9 / 2009$ & Positive & $40.2 \%$ & $5.25 \%$ & 64 \\
8 & $6 / 11 / 2008$ & $7 / 14 / 2008$ & Positive & $21.7 \%$ & $9.31 \%$ & 23 \\
9 & $4 / 9 / 2008$ & $5 / 7 / 2008$ & Positive & $22.8 \%$ & $7.97 \%$ & 37 \\
10 & $10 / 26 / 2007$ & $12 / 7 / 2007$ & Positive & $25.4 \%$ & $7.68 \%$ & 22 \\
Mean & & & & $25.62 \%$ & $7.26 \%$ & 30 \\
\hline
\end{tabular}


accounted for three positive and one, large negative shock, while the 2014/2015 period accounted for two negative and one positive shock. We see from the table that the average percent change and standard deviation for negative events ( -32.8 percent and 8.6 percent) is larger than these averages (25.6 percent and 7.6 percent) for positive events. In addition, the average length of time for the shock is longer for negative events than positive.

The event length is measured by the number of consecutive days in which crude oil prices are 20 percent greater or less than they were 60 days prior. We deemed a shock to end when for 3 consecutive days, crude oil prices stopped being 20 percent higher or lower than the prices from the rolling 60 days prior.

Event 4 was the longest shock, followed by Event 2. Both of these shocks are negative with the former occurring around the height of the financial crisis and the latter occurring around the time OPEC voted in late 2014 not to reduce or hold crude oil output constant. Events 1 and 4 exhibited the largest negative returns of -38 and -40 percent respectively. Event 7 , which occurred toward the end of the 2008/2009 recession, exhibited the largest positive percent increase.

The interest of this paper is to examine the effect of oil price shocks or structural breaks on US stock market returns across sectors that would likely be impacted by oil price movements. Since we are interested in differences in sectors rather than individual companies, we used electronic traded funds (ETFs) to capture the effect on the complete sector. Table 2 shows the 20ETFs used in this study.

The oil producing sector includes each of the sectors engaged in the production and transportation of crude and refined oil ${ }^{3}$. Our hypothesis is that the oil producing and banking sectors will exhibit positive/negative abnormal returns during periods of increasing/decreasing crude oil prices, while the oil consuming sectors will exhibit the opposite. We also expect the effects to be asymmetrical between positive and negative shocks, with the absolute value of the CARs in the producing and banking sector being greater in negative shocks than positive

Table 2. ETFs by sector.

\begin{tabular}{cccc}
\hline Oil producing sector & Oil consuming sector & Banking sector & Neutral sector \\
\hline $\begin{array}{c}\text { Oil Exploration and } \\
\text { Production } \\
\text { Integrated Oil } \\
\text { Producers }\end{array}$ & Refining & Large banks & $\begin{array}{c}\text { Information } \\
\text { Technology }\end{array}$ \\
Oil Pipelines & Automobiles & Regional banks & Utilities \\
$\begin{array}{c}\text { Oil Equipment \& } \\
\text { Services }\end{array}$ & Shipping & S\&P Bank & Telecommunications \\
$\begin{array}{c}\text { Leisure and } \\
\text { entertainment }\end{array}$ & $\begin{array}{c}\text { Equal Weight } \\
\text { Financials }\end{array}$ & Staples \\
& $\begin{array}{c}\text { Transportation } \\
\text { (rails and cargo) }\end{array}$ & & Health care \\
& & Consumer \\
\hline
\end{tabular}

*Includes approximately 25 to 30 percent real estate.

${ }^{3}$ The sector includes integrated oil and gas companies, who are both producers and refiners. 
shocks. See Table 3 for the mean CARs by sector for positive and negative shocks.

For the oil consuming sector, we reviewed publications that estimated the largest oil consuming sectors ${ }^{4}$. For three of the indices (refining, automobiles, and petrochemical), we constructed the ETF by calculating a weighted ${ }^{5}$ average stock price of the four largest firms in the sector. The banking sector includes large, global banks, an equal weighted ETF of financial firms, and two ETFs covering regional banks, all of which provide credit to the oil and gas sector. As such, we expect the financial sector to move in tandem with the oil producing sector. Finally, we identified six other major sub sectors, which we expect to be neutral and, therefore, not exhibit significant abnormal returns relative to oil and gas price movements.

\subsection{Methodology}

To understand the effect of crude oil price movements on stock prices, we used a two-step process in which we obtained abnormal returns for 20 ETFs during the event window and then assessed the impact of key factors that influenced these abnormal returns.

\subsubsection{Abnormal Return Procedure}

The approach for calculating the abnormal returns was based on MacKinlay's [21] technique whereby the actual stock market return during the event window for each company is compared to the expected return as follows:

$$
A R_{i t}=R_{i t}-E\left(R_{i t} \mid X_{i}\right)
$$

where $A R_{i p} R_{i p}$ and $E\left(R_{i t} \mid X_{i}\right)$ are the abnormal returns, actual returns, and the expected returns for period $t . X_{t}$ is the conditioning information for the normal return, based on the market model, where $X_{i}$ is the market return. The market model is the following:

$$
E\left(R_{i t} \mid X_{t}\right)=\alpha_{i}+\beta_{i} R_{m t}+\varepsilon_{i t}
$$

with $E(e)=0$ and $\operatorname{var}(e)=\sigma^{2} \dot{\varepsilon}$, where $R_{i t}$ and $R_{m t}$ are the period-t returns on security or $\mathrm{ETF}_{\mathrm{i}}$ and the market portfolio or S\&P 500, respectively. This approach assumes a stable linear relation between the market and a security's return

Table 3. CARs by sector (Positive versus negative shocks).

\begin{tabular}{ccccccc}
\hline & \multicolumn{3}{c}{ Positive Oil Shocks } & \multicolumn{3}{c}{ Negative Oil Shocks } \\
\hline Sector & $-10 \_5$ CARs & $-10 \_10 C A R s$ & $-10 \_30 C A R s$ & $-10 \_5 C A R s$ & $-10 \_10 C A R s$ & $-10 \_30 C A R s$ \\
\hline Producer & $-0.7 \%$ & $-1.1 \%$ & $-5.8 \%^{* * *}$ & $-2.9 \%^{* * *}$ & $-5.9 \%^{* * *}$ & $-5.6 \%^{* * *}$ \\
Banking & $-1.1 \%$ & $-1.0 \%$ & $-1.2 \%$ & $4.7 \%^{*}$ & $5.8 \%^{*}$ & $6.0 \%$ \\
Consumer & $-1.9 \%^{*}$ & $-2.2 \%^{*}$ & $-3.9 \%^{* *}$ & $1.8 \%$ & $0.7 \%$ & $1.9 \%$ \\
Neutral & $0.2 \%$ & $0.8 \%$ & $1.5 \%$ & $-0.2 \%$ & $-0.2 \%$ & $-0.5 \%$ \\
\hline
\end{tabular}

${ }^{\star}$ Significant at the 10 percent level, ${ }^{\star *}$ Significant at the 5 percent level, ${ }^{* *}$ Significant at the 1 percent level.

${ }^{4}$ See http://www.opec.org/opec_web/en/publications/340.htm, page 95.

${ }^{5}$ The ETFs were weighted by sales. 
$[21]^{6}$.

Rearranging the terms, we get

$$
\widehat{A R}_{i e}=R_{i t}-\alpha_{i}-\beta_{i} R_{m t}
$$

with the variance being

$$
\operatorname{Var}(\widehat{A R})=\sigma^{2} \varepsilon+\frac{1}{L}\left[1+\frac{\left(R_{m t}-\mu_{m}\right)^{2}}{\sigma_{m}^{2}}\right]
$$

In this equation, $L$ is the length of the estimation window, so as $L$ becomes large (e.g. 120 days) the second term, which accounts for the additional variance in the sampling error of $\alpha$ and $\beta$, approaches zero. The variance of the abnormal return then becomes the variance of the market model. The abnormal return for each ETF $(i)$ is the difference between the actual return during the event window $(t)$ for each event and the expected return $E\left(R_{i t} \mid X_{t}\right)$ from the market model. We used a 120 day estimation window, stopping 10 days prior to the event, to determine the expected return $E\left(R_{i t} \mid X_{t}\right)$. Abnormal returns were calculated for three windows $(-10,5),(-10,10)$, and $(-10,30)$.

Cumulative abnormal returns (CARs), or the sum of the abnormal returns, are then calculated over the event windows per event for each ETF.

$$
C A R_{i}=\sum_{1}^{20} A R_{i t}
$$

While CARs were gathered for three event windows, the regression estimation was performed on the $(-10,10)$ window. The results were similar between windows, but the fit was the best using the 20 day window.

\subsubsection{Summary Data}

Table 3 shows the average CARs for the three event windows for the producer, consumer, banking, and neutral sectors and the significance of these sectors for positive and negative shocks.

From viewing the CARs by sector and type of shock, we see that the abnormal returns are large and significant in the producing sector for negative shocks. For positive shocks, producer CARs are also surprisingly negative, though not significant, except for the $(-10,30)$ window. This asymmetry can likely be attributed to the notion that negative shocks are associated with greater uncertainty regarding the investment opportunities in the producing sector than the optimism that might occur in a positive shock. The negative average CARs we calculated are surprising, though only significant in the $(-10,30)$ window. This result can possibly be explained by uncertainties surrounding contractionary monetary policy, as suggested by Balke et al. [13], that might accompany positive oil shocks.

The consuming sector shows the opposite effect from the producing sector with negative, significant CARs associated with positive oil shocks, and positive CARs exhibited in negative oil shocks. However, the consumer CARs are small

${ }^{6}$ Some of this write-up was taken from MacKinlay, 1997. 
and not significant in negative shocks.

The average CARs in the banking sector are positive but insignificant in the negative events. In contrast, the average banking sector CARs are negative in positive oil shock events and significant in one of the windows. Finally, we see the CARs, as expected, are small and insignificant in the neutral sector.

To look at the $(-10,10)$ CARs by ETFs in the four sectors, we graphed the ETF abnormal returns per event as shown in Figure 2.

From the graphs, we see negative abnormal returns in the banking sector in each of the windows, except for event 4 , which exhibit large significant abnormal returns. Most likely the returns in event 4 were influenced by the financial crisis, which hit the financial services sector the hardest.

In the producer sector we find negative abnormal returns during negative events and mixed abnormal returns during positive events. We also see differences
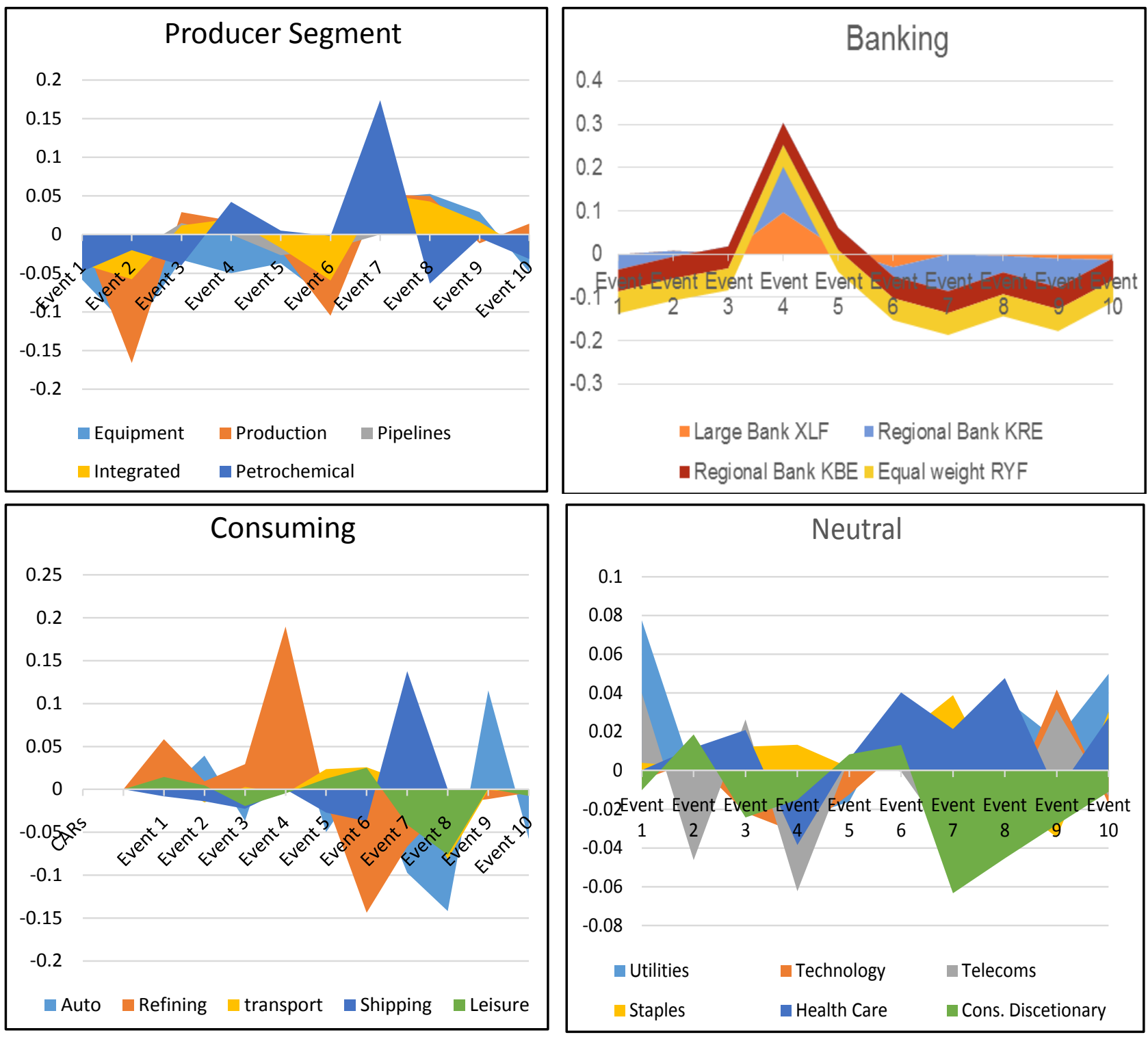

Figure 2. ETF abnormal returns by event by sector. 
by sub-sector, with the oil equipment and producer ETFs being more volatile than the integrated oil ETF.

For the consuming sector we see mixed results. The leisure and refining sectors show the expected results with positive returns during negative shocks and negative returns during positive shocks. In contrast, the shipping and automotive sectors show counter results, perhaps suggesting that these sectors are driven more by cyclicality than by crude oil prices.

Finally, as expected, we do not find a pattern relating to CARs per event in the neutral sector.

\subsubsection{Regression Analysis}

To determine the factors that are impacting cumulative average returns by sector, we turned to a regression Equation (6) with event and ETF-specific factors as covariates. The equation for this regression is the following:

$$
\begin{aligned}
\widehat{C A R}_{i}= & \beta_{1}+\beta_{2} \text { Event }_{\text {char }}+\beta_{3} \text { Sectork }+\beta_{4}\left(\text { Event }_{\text {char }} * \text { Sectork }\right) \\
& +\beta_{5} \text { recession }_{j}+\beta_{6} \text { Firm char }_{i}+\varepsilon
\end{aligned}
$$

Subscript $j$ denotes the events, $i$ the company, and $k$ the sectors-producing, banking, consuming and neutral. Event char $_{j}$ refers to a matrix of event characteristics, which are percent change (logged), event standard deviation (logged) or variability, and event velocity (log of percent change). Percent change refers to the increase or decline in oil prices from the period beginning 60 days prior to the event and lasting to the end of the event. In this manner we are capturing investor perceptions relating to the depth of the shock. The variables used are demeaned, representing the difference between the percent change in oil prices during the event and the average percent change among all positive or negative events. The velocity of the change in the shock (the log of the absolute value of the demeaned oil price change), measures the speed at which the shock occurred. In addition, we assessed the variability in oil prices by taking the standard deviation of the change in oil prices during the 60 day time period. These event characteristics were included separately and also interacted with sectors and regressed relative to the CARs. Separate regressions, however, were used for velocity and percent change due to multi-collinearity issues.

In addition, we included firm characteristics to include the asset size and debt to equity of the companies. Since we are covering ETFs, we used the weighted average of the companies in each ETF to calculate the asset size and the debt to equity. We expect larger asset size to have a positive impact on the CARs of an ETF, since larger companies are likely to be in a better financial condition than are smaller companies. Using similar reasoning, we expect debt to equity levels to be inversely related to CARs. See Table 4 for summary statistics relating to individual ETF characteristics.

Finally, like Mohanty et al. [14], we calculated the percent return or Run-up for the period leading up to the event window $(-60,-10)$. We calculate this variable to control for the possibility that investors bid up or sold the stock prior to the event window. 
Table 4. Summary Data-ETF characteristics by sector.

\begin{tabular}{ccc}
\hline Sector & Assets & Debt to Equity \\
\hline Producing & $\$ 223,804$ & 1.05 \\
Banking & $\$ 3,991,813$ & 1.05 \\
Consuming & $\$ 120,863$ & 1.80 \\
Neutral & $\$ 500,145$ & 1.08 \\
\hline
\end{tabular}

In addition, we ran a second specification with the sample restricted to nonrecession years. We employ this specification because the recession may be causing the oil shock (s) and, therefore, potentially distorting the effect on particular sectors (e.g. banking), as the period for which the "normal" returns were calculated occurred at a time of instability. As such, this regression did not include the oil shocks that occurred in 2008 or the first half of 2009.

\section{Results}

Table 5 and Table 6 show the results from the event study regression for the full sample and the non-recession events respectively. The first column provides findings for the total sample. Columns 2 and 3 show results for the positive and negative shocks respectively, with the sectors interacted with percent change or the depth of the shock. Columns 4 and 5 are similar except they have the sectors interacted with the velocity of the shock ${ }^{7}$.

We see from Table 5, Column 1 that the coefficient for the producing sector is negative and significantly (weakly) different from the neutral sector, indicating that the producing sector exhibited abnormal returns during oil shocks. Looking at Column 5, we see that this result is driven, as expected by negative oil shocks, where the coefficients are negative and significant.

Looking further at the producer sector, we find in Column 1 that the coefficient for producer times percent change is positive and weakly significant. This result appears to be driven by positive oil shocks as evidenced by the positive, significant coefficient in Column 2 for producer interacted with percent change. This result suggests that a 1 percent increase in oil prices results in a 0.63 percent increase in the abnormal returns in the producing sector during the event window of a positive oil shock. The coefficient for the interaction term (producer*percent change) is even larger in the non-recession specification (Table 6) for positive events.

For negative oil shocks we find in Table 6 the coefficient for the interaction term between the producer sector and percent change to be negative and significant, indicating that higher percent change in oil prices in negative shocks would lead to lower abnormal returns. This finding, while initially counterintuitive, suggests that in a negative oil shock, investors may ignore or look through periods of increasing oil prices, believing that the negative shock will cause longer term disruptions overall and particularly in the oil producing sector. This ${ }^{7}$ We could not interact percent change with the sectors and velocity with the sectors in one regression due to multi-colinearity concerns. 
Table 5. Regression results.

\begin{tabular}{|c|c|c|c|c|c|}
\hline & Total & Positive & Negative & Positive & Negative \\
\hline VARIABLES & CARs10_10 & CARs10_10 & CARs10_10 & CARs10_10 & CARs10_10 \\
\hline \multirow[t]{2}{*}{ recession } & 0.0131 & 0.000621 & -0.0170 & -0.00586 & $-0.385^{\star * *}$ \\
\hline & $(0.0169)$ & $(0.0142)$ & $(0.0573)$ & $(0.0156)$ & $(0.0903)$ \\
\hline \multirow[t]{2}{*}{ producing } & $-0.0283^{*}$ & -0.00193 & -0.0330 & 0.0372 & $-0.520^{* * *}$ \\
\hline & $(0.0159)$ & $(0.0169)$ & $(0.0250)$ & $(0.0390)$ & $(0.180)$ \\
\hline \multirow{2}{*}{ consuming } & -0.00759 & -0.0261 & 0.0247 & -0.0121 & $0.238^{* *}$ \\
\hline & $(0.0164)$ & $(0.0191)$ & $(0.0209)$ & $(0.0549)$ & $(0.115)$ \\
\hline \multirow[t]{2}{*}{ banking } & 0.00911 & -0.0231 & 0.0603 & -0.0218 & $1.025^{* * *}$ \\
\hline & $(0.0174)$ & $(0.0185)$ & $(0.0410)$ & $(0.0400)$ & $(0.355)$ \\
\hline \multirow[t]{2}{*}{ Percent change } & -0.0424 & -0.163 & 0.0786 & 0.0814 & $-0.640^{* * *}$ \\
\hline & $(0.143)$ & $(0.104)$ & $(0.197)$ & $(0.109)$ & $(0.126)$ \\
\hline \multirow[t]{2}{*}{ prod $*$ percent change } & $0.369^{*}$ & $0.632^{\star * *}$ & 0.0251 & & \\
\hline & $(0.195)$ & $(0.169)$ & $(0.299)$ & & \\
\hline consume ${ }^{\text {percent }}$ & 0.0194 & 0.145 & -0.0956 & & \\
\hline change & $(0.196)$ & $(0.302)$ & $(0.167)$ & & \\
\hline \multirow[t]{2}{*}{$\begin{array}{c}\text { Bank»percent } \\
\text { change }\end{array}$} & $-0.438^{\star *}$ & 0.286 & $-1.215^{* * *}$ & & \\
\hline & $(0.207)$ & $(0.193)$ & $(0.425)$ & & \\
\hline prod $\star_{\text {velocity }}$ & & & & 0.0103 & $-0.187^{* * *}$ \\
\hline (logged) & & & & $(0.00882)$ & $(0.0648)$ \\
\hline Consume ${ }^{\star}$ velocity & & & & 0.00464 & $0.0810^{*}$ \\
\hline (logged) & & & & $(0.0135)$ & $(0.0417)$ \\
\hline \multirow[t]{2}{*}{ Bank*velocity } & & & & 0.00123 & $0.370^{* * *}$ \\
\hline & & & & $(0.00958)$ & $(0.124)$ \\
\hline \multirow[t]{2}{*}{ Variation (logged) } & -0.0164 & -0.0314 & 0.0484 & -0.0311 & $0.413^{* * *}$ \\
\hline & $(0.0231)$ & $(0.0196)$ & $(0.0651)$ & $(0.0204)$ & $(0.0928)$ \\
\hline \multirow[t]{2}{*}{ Velocity (logged) } & 0.00320 & -0.000185 & -0.0445 & -0.00322 & 0.0381 \\
\hline & $(0.00520)$ & $(0.00390)$ & $(0.0295)$ & $(0.00743)$ & $(0.0436)$ \\
\hline \multirow[t]{2}{*}{ Assets (logged) } & 0.00366 & 0.00220 & 0.0110 & 0.00232 & 0.0116 \\
\hline & $(0.00444)$ & $(0.00531)$ & $(0.00971)$ & $(0.00535)$ & $(0.00817)$ \\
\hline Debt/Equity & 0.000227 & 0.000547 & -0.00320 & 0.00361 & -0.00125 \\
\hline (logged) & $(0.00602)$ & $(0.00524)$ & $(0.00875)$ & $(0.00528)$ & $(0.00727)$ \\
\hline \multirow[t]{2}{*}{ RUNWAY } & $0.0714^{*}$ & -0.0383 & 0.0991 & -0.0640 & 0.113 \\
\hline & $(0.0415)$ & $(0.0588)$ & $(0.0934)$ & $(0.0635)$ & $(0.0693)$ \\
\hline \multirow[t]{2}{*}{ Constant } & -0.00651 & 0.0397 & -0.362 & 0.0314 & $-0.828^{* * *}$ \\
\hline & $(0.0786)$ & $(0.0857)$ & $(0.244)$ & $(0.0900)$ & $(0.224)$ \\
\hline Observations & 170 & 96 & 74 & 96 & 74 \\
\hline R-squared & 0.158 & 0.244 & 0.502 & 0.164 & 0.620 \\
\hline
\end{tabular}

Standard errors in parentheses, ${ }^{* *} \mathrm{p}<0.01,{ }^{* *} \mathrm{p}<0.05,{ }^{*} \mathrm{p}<0.1$.

result, however, appears to be diminished during recession events, as the coefficient for the interaction term (producingæpercent change) is not significant in 
Table 6. Regression results (no recession).

\begin{tabular}{|c|c|c|c|c|c|}
\hline & Total & Positive & Negative & Positive & Negative \\
\hline VARIABLES & CARs10_10 & CARs10_10 & CARs10_10 & CARs10_10 & CARs10_10 \\
\hline \multirow[t]{2}{*}{ producing } & $-0.0324^{\star *}$ & -0.0227 & -0.0131 & 0.0371 & $-0.528^{\star * \star}$ \\
\hline & $(0.0137)$ & $(0.0195)$ & $(0.0137)$ & $(0.0454)$ & $(0.137)$ \\
\hline \multirow[t]{2}{*}{ consuming } & $-0.0234^{\star}$ & -0.0332 & -0.00403 & -0.0112 & 0.116 \\
\hline & $(0.0139)$ & $(0.0202)$ & $(0.0127)$ & $(0.0588)$ & $(0.133)$ \\
\hline \multirow[t]{2}{*}{ banking } & -0.0151 & -0.00722 & $-0.0321^{\star * *}$ & -0.00187 & 0.105 \\
\hline & $(0.0150)$ & $(0.0194)$ & $(0.0101)$ & $(0.0458)$ & $(0.109)$ \\
\hline \multirow[t]{2}{*}{ Percent change } & -0.109 & -0.155 & -0.140 & 0.0705 & $-0.513^{\star * *}$ \\
\hline & $(0.117)$ & $(0.110)$ & $(0.117)$ & $(0.108)$ & $(0.110)$ \\
\hline \multirow{2}{*}{$\begin{array}{c}\text { prod }{ }^{\star} \text { percent } \\
\text { change }\end{array}$} & 0.261 & $0.718^{\star * *}$ & $-0.418^{\star *}$ & & \\
\hline & $(0.167)$ & $(0.194)$ & $(0.189)$ & & \\
\hline consume ${ }^{\star}$ percent & 0.134 & 0.128 & 0.114 & & \\
\hline change & $(0.164)$ & $(0.317)$ & $(0.151)$ & & \\
\hline \multirow{2}{*}{$\begin{array}{c}\text { Bank }{ }^{\star} \text { percent } \\
\text { change }\end{array}$} & 0.172 & 0.194 & $0.328^{\star *}$ & & \\
\hline & $(0.180)$ & $(0.212)$ & $(0.133)$ & & \\
\hline prod $*^{*}$ elocity & & & & 0.0122 & $-0.185^{\star \star \star}$ \\
\hline (logged) & & & & $(0.00933)$ & $(0.0491)$ \\
\hline consume*velocity & & & & 0.00643 & 0.0428 \\
\hline (logged) & & & & $(0.0135)$ & $(0.0472)$ \\
\hline Bank ${ }^{*}$ elocity & & & & 0.00170 & 0.0468 \\
\hline (logged) & & & & $(0.0101)$ & $(0.0422)$ \\
\hline \multirow[t]{2}{*}{ Variation (logged) } & -0.0276 & -0.0240 & $0.129^{\star *}$ & -0.0266 & $0.355^{\star * *}$ \\
\hline & $(0.0192)$ & $(0.0193)$ & $(0.0521)$ & $(0.0206)$ & $(0.0647)$ \\
\hline \multirow[t]{2}{*}{ Velocity (logged) } & -0.000662 & $-5.95 \mathrm{e}-05$ & -0.0275 & -0.00392 & $0.0599^{*}$ \\
\hline & $(0.00401)$ & $(0.00405)$ & $(0.0189)$ & $(0.00755)$ & $(0.0347)$ \\
\hline \multirow[t]{2}{*}{ Assets (logged) } & 0.000488 & -0.00118 & 0.00484 & -0.00126 & $0.00526^{* *}$ \\
\hline & $(0.00364)$ & $(0.00597)$ & $(0.00321)$ & $(0.00617)$ & $(0.00224)$ \\
\hline Debt/Equity & 0.00682 & 0.00393 & 0.00462 & 0.00820 & 0.00397 \\
\hline (logged) & $(0.00509)$ & $(0.00561)$ & $(0.00623)$ & $(0.00550)$ & $(0.00591)$ \\
\hline \multirow[t]{2}{*}{ RUNWAY } & 0.0188 & -0.0130 & 0.0914 & -0.0420 & 0.0702 \\
\hline & 0.000488 & -0.00118 & 0.00484 & -0.00126 & $0.00526^{* *}$ \\
\hline \multirow[t]{2}{*}{ Constant } & 0.0545 & 0.0703 & $-0.376^{\star \star}$ & 0.0638 & $-0.566^{\star * *}$ \\
\hline & $(0.0625)$ & $(0.0909)$ & $(0.155)$ & $(0.0971)$ & $(0.134)$ \\
\hline Observations & 123 & 66 & 57 & 66 & 57 \\
\hline R-squared & 0.115 & 0.287 & 0.493 & 0.165 & 0.658 \\
\hline
\end{tabular}

Standard errors in parentheses, ${ }^{* * *} \mathrm{p}<0.01,{ }^{* *} \mathrm{p}<0.05,{ }^{*} \mathrm{p}<0.1$.

the total sample (Table 5, column 3).

In looking at Table 6, we see the coefficient for the consuming sector is negative and weakly significant, indicating that the consumer sector is hurt by higher 
oil prices in non-recession events. We do not find this result, however, in Table 5 (all events), suggesting that this finding may be reduced by a recession. Furthermore, none of the coefficients for the interaction terms between the consumer sector and the event characteristics are significant.

Regarding the banking sector, we find large differences between Table 5 and Table 6, leading us to believe the recession plays a major part in the effect that oil shocks have on the banking sector. In Table 5, we find a negative, significant coefficient for the banking sector when interacted with percent change during negative shocks. In contrast, in Table 6 we find and a positive, highly significant coefficient for the banking sector when interacted with percent change during positive shocks in the non-recession specification. As such, we believe that the recession had a strong effect on the banking sector, distorting the abnormal returns. The result in the non-recession specification would suggest that as oil prices increase during negative oil shocks, so too do the CARs in the banking sector. These results indicate that the banking sector may be strongly affected by negative oil price shocks during non-recessionary periods, most likely due to credit concerns.

Overall, we find the coefficient for the variation (logged) of the change in oil prices to have a significant effect on the CARs during negative oil shocks. This result indicates that uncertainty due to variable oil prices may have a detrimental effect on stock prices in negative oil shocks, though not in positive oil shocks. Also, we find evidence, in Column 3, that the recession has a negative effect on abnormal returns during a negative oil shock.

Finally, from looking at column 5, Table 6, we see the asset size of the companies in the ETFs to be significant in one of the negative oil shock specifications. This result suggests that investors tend to bid up larger companies during a negative oil shock.

Our results can be summarized in Table 7, which compares the results to our

Table 7. Summary of results.

\begin{tabular}{|c|c|c|c|}
\hline Specification & Variable & Hypothesis & Results \\
\hline \multirow[t]{3}{*}{ Overall } & Sector & differences & (-) Producers \\
\hline & $\begin{array}{l}\text { Sector*change } \\
\text { or intensity }\end{array}$ & differences & $(+)$ producer \\
\hline & Variation or Velocity & differences & Not significant \\
\hline \multirow[t]{3}{*}{ Positive shocks } & Sector & $\begin{array}{l}\text { (+) Producers } \\
(-) \text { consumers }\end{array}$ & (-) Producers \\
\hline & $\begin{array}{l}\text { Sector*change } \\
\text { or intensity }\end{array}$ & differences & (+) Producers \\
\hline & Variation & differences & Not significant \\
\hline \multirow[t]{3}{*}{ Negative shocks } & Sector & $\begin{array}{l}\text { (-) Producers } \\
(-) \text { Banking }\end{array}$ & $\begin{array}{l}(-) \text { Banking } \\
(+) \text { producer }\end{array}$ \\
\hline & $\begin{array}{l}\text { Sector*change } \\
\text { or intensity }\end{array}$ & differences & (-) Producers \\
\hline & $\begin{array}{c}\text { Percent change } \\
\text { Variation }\end{array}$ & differences & $\begin{array}{l}\text { (-) Percent change } \\
(+) \text { Variation }\end{array}$ \\
\hline
\end{tabular}


initial hypothesis. As indicated earlier, we expected there to be significant abnormal returns by sector, which we found for producers in all events and also in negative oil shocks. We also found positive abnormal returns associated with the producer sector interacted with percent change. For negative shocks, we found negative returns in the banking sector (in non-recession events) and in the producing sector. We also found the percent change to have a negative, significant effect on CARs, while variation has a positive significant effect during negative oil shocks.

These results certainly provide evidence in support of our hypothesis that prolonged oil shocks will produce differential effects by sector, with differences based on depth, variability, and velocity of the shock. In addition, we provide evidence suggesting differential investor responses to negative and positive oil shocks overall and by sector.

\section{Conclusions}

This study examined the effects of long-term changes in crude oil prices on stock prices in the US producer, consumer and banking sectors. Our methodology was to assess how oil price shocks affected the abnormal returns of key ETFs within the producer, consumer, banking and neutral sectors over a ten year time period spanning from 2006 through 2015. We found, as expected, that abnormal returns in the producer sector were positively associated with increasing oil prices, particularly with larger positive shocks. In contrast, we found that changes in the price and the velocity of the change in oil prices negatively influenced abnormal returns in the banking sector during negative oil shocks. Finally, we found that the abnormal returns in the consumer sector are adversely affected by higher oil prices during positive oil shocks, but we did not find evidence of any significant effect on the CARs in the consumer sector during negative oil shocks.

Our results suggest that there are indeed significant abnormal returns in key economic sectors affected by oil price changes. Like past studies, we found the abnormal returns to be asymmetric, suggesting different effects occurring during positive and negative oil shocks. Our findings provide further evidence regarding investor uncertainty and sectorial shifts that accompany oil price shocks. It is left to other research to disentangle these effects further.

\section{Acknowledgements}

I am really grateful to the anonymous referees whose comments have significantly improved this paper.

\section{References}

[1] Hamilton, J. (1983) Oil and the Macroeconomy since World War II. The Journal of Political Economy, 91, 228-248. https://doi.org/10.1086/261140

[2] Ross, S. (1989) Information and Volatility: The No-Arbitrage Martingale Approach to Timing and Resolution Irrelevancy. Journal of Finance, 44, 1-17. https://doi.org/10.1111/j.1540-6261.1989.tb02401.x 
[3] Ferderer J. (1996) Oil Price Volatility and the Macro Economy: A Solution to the Asymmetry Puzzle. Journal of Macroeconomics, 18, 253-273.

[4] Lee, K., S. Ni, S. and Ratti, R.A. (1995) Oil Shocks and the Macroeconomy: The Role of Price Variability. Journal of Energy, 16, 39-56.

https://doi.org/10.5547/issn0195-6574-ej-vol16-no4-2

[5] Sadorsky, P. (1999) Oil Price Shocks and Stock Market Activity. Energy Economics, 21, 449-469. https://doi.org/10.1016/S0140-9883(99)00020-1

[6] Huang, R., Masulis, R. and Stoll, H. (1996) Energy Shocks and Financial Markets. Journal of Futures Markets, 16, 1-27. https://doi.org/10.1002/(SICI)1096-9934(199602)16:1<1::AID-FUT1>3.0.CO;2-Q

[7] Hammoudeh, S. and Li, H. (2005) Oil Sensitivity and Systematic Risk in Oil Sensitive Stock Indices. Journal of Economics and Business, 57, 1-21. https://doi.org/10.1016/j.jeconbus.2004.08.002

[8] Mohanty, S. and Nandha, M. (2011) Oil Risk Exposure: The Case of the U.S. Oil and Gas Sector. Financial Review, 46, 165-191. https://doi.org/10.1111/j.1540-6288.2010.00295.x

[9] Sadosky, P. (2001) Risk Factors in Stock Returns of Canadian Oil and Gas Companies. Energy Economics, 23, 17-28. https://doi.org/10.1016/S0140-9883(00)00072-4

[10] Chen, N.F., Roll, R. and Ross, S.A. (1986) Economic Forces and the Stock Market. Journal of Business, 59, 383-403. https://doi.org/10.1086/296344

[11] Hamao, Y., Masulis, R. and Ng, V. (1989) Correlations in Price Changes and Volatility across International Stock Markets, The Review of Financial Studies, 3, 281307. https://doi.org/10.1093/rfs/3.2.281

[12] Hamilton, J. (1988) Rational-Expectations Econometric Analysis of Changes in Regime: An Investigation of the Term Structure of Interest Rates. Journal of Economic Dynamics and Control, 12, 385-423. https://doi.org/10.1016/0165-1889(88)90047-4

[13] Balke, N., Brown, S. and Yücel, M. (2002) Oil Price Shocks and the U.S. Economy: Where Does the Asymmetry Originate? The Energy Journal, 23, 27-52. https://doi.org/10.5547/ISSN0195-6574-EJ-Vol23-No3-2

[14] Mohanty, S., Akhigbe, A., Al-Khyal, T. and Turki Bugshan, T. (2013) Oil and Stock Market Activity When Prices Go Up and Down: The Case of the Oil and Gas Industry. Review of Quantitative Financial Accounting, 41, 253-272.

https://doi.org/10.1007/s11156-012-0309-9

[15] Kilian, L. (2008b) The Economic Effects of Energy Price Shocks. Journal of Economic Literature, 46, 871-1009. https://doi.org/10.1257/jel.46.4.871

[16] Bernanke, B. (1983) The Determinants of Investment: Another Look. American Economic Review, 73, 2 71-275.

[17] Pindyck, R.S. (1991) Irreversibility, Uncertainty, and Investment. Journal of Economic Literature, 29, 1110-1148.

[18] Lilian, D. (1982) Sectoral Shifts and Cyclical Unemployment. Journal of Political Economics, 90, 777-794. https://doi.org/10.1086/261088

[19] Davis, S. (1987) Allocative Disturbances and Specific Capital in Real Business Cycles Theories. American Economic Review, 77, 326-332.

[20] Killian, L. and Park, C. (2009) The Impact of Oil Price Shocks on the U.S. Stock Market. International Economic Review, 50, 1267-1287. https://doi.org/10.1111/j.1468-2354.2009.00568.x

[21] Mackinlay, C. (1997) Event Studies in Finance and Economics. Journal of Economic Literature, 35, 13-39. 
Submit or recommend next manuscript to SCIRP and we will provide best service for you:

Accepting pre-submission inquiries through Email, Facebook, LinkedIn, Twitter, etc. A wide selection of journals (inclusive of 9 subjects, more than 200 journals)

Providing 24-hour high-quality service

User-friendly online submission system

Fair and swift peer-review system

Efficient typesetting and proofreading procedure

Display of the result of downloads and visits, as well as the number of cited articles Maximum dissemination of your research work

Submit your manuscript at: http://papersubmission.scirp.org/

Or contact me@scirp.org 